\title{
Task Technical Plan for Studies of Oxygen Consumption in the Catalyzed Hydrolysis of Tetraphenylborate lon
}

by

S. D. Fink

Westinghouse Savannah River Company

Savannah River Site

Aiken, South Carolina 29808

This paper was prepared in connection with work done under the above contract number with the U.S. Department of Energy. By acceptance of this paper, the publisher and/or recipient acknowledges the U. S. Government's right to retain a nonexclusive, royalty-free license in and to any copyright covering this paper, aiong with the right to reproduce and to authorize others to reproduce all or part of the copyrighted paper. 


\section{DISCLAIMER}

Portions of this document may be illegible electronic image products. Images are produced from the best available original document. 


\section{DISCLAIMER}

This report was prepared as an account of work sponsored by an agency of the United States Government. Neither the United States Government nor any agency thereof, nor any of their employees, makes any warranty, express or implied, or assumes any legal liability or responsibility for the accuracy, completeness, or usefulness of any information, apparatus, product, or process disclosed, or represents that its use would not infringe privately owned rights. Reference herein to any specific commercial product, process, or service by trade name, trademark, manufacturer, or otherwise does not necessarily constitute or imply its endorsement, recommendation, or favoring by the United States Government or any agency thereof. The views and opinions of authors expressed herein do not necessarily state or reflect those of the United States Government or any agency thereof.

This report has been reproduced directly from the best available copy.

Available to DOE and DOE contractors from the Office of Scientific and Technical Information, P.O. Box 62, Oak Ridge, TN 37831; prices available from (615) 576-8401.

Available to the public from the National Technical Information Service, U.S. Department of Commerce, 5285 Port Royal Road, Springfield, VA 22161. 
M. L. Hyder

WSRC-RP-96-0612, Rev. 0

Page 1 of 10

WESTINGHOUSE SAVANNAH RIVER COMPANY

SAVANNAH RIVER TECHNOLOGY CENTER

Keywords:

In-Tank Precipitation

Chemical Analysis

Electrochemistry

Retention: Permanent

December 9, 1996

To: S. D. Fink, 773-A

From: M. L. Hyder, 773-A

TASK TECHNICAL PLAN FOR STUDIES OF OXYGEN CONSUMPTION IN THE CATALYZED FYDROLYSIS OF TETRAPHENYLBORATE ION (U)

Approved by:

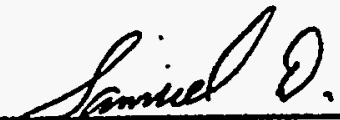

S. D. Fink, Mgr:, WPS

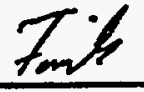

$12-11-96$

(Date)

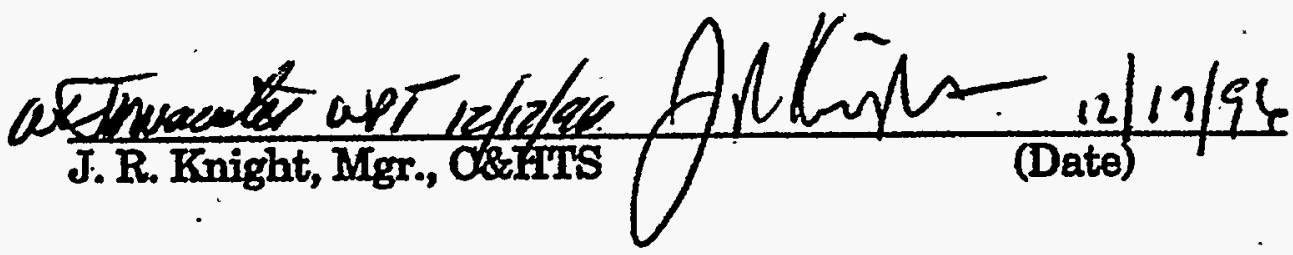

Nal

It limes

$12 / 10 k 6$

J. T. Carter, In-Tank Precipitation Flowsheet Review (Date)

Awe 20 Share

J. E. Marra, HLWE Review

$12 / 13 / 96$

(Date)

Classification Review:

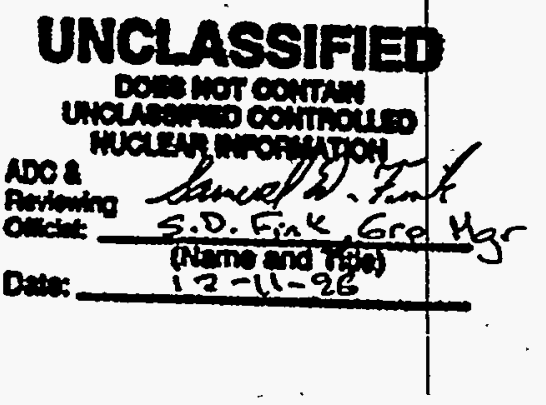




\section{INTRODUCTION}

This document presents the plan for studies of how dissolved oxygen affects the catalytic decomposition of the tetraphenylborate ion in alkaline aqueous solution. Related experiments, including a series of scoping tests, suggest that the role of dissolved oxygen may be significant in this process. 2 The planned sequence of studies involves both solutions of sodium tetraphenylborate (NaTPB) and of its decomposition product phenylboronic acid (PBA), singly and in combination. The proposed work is being undertaken in response to the High Level Waste Engineering request for studies to develop an understanding of the role of oxygen in copper oxidation and solubility, catalyst activation and induction period, as documented in HIE-TTR-97011, and is part of the implementation plan for addressing the safety issues embodied in DNFSB Recommendation 96-1.

\section{Background}

Excess tetraphenylborate.ion remaining after the precipitation of cesium in Tank 48H can decompose relatively quickly to simpler boron compounds and organic compounds, primarily benzene. Unexpectedly, this decomposition occured over a period of only a few weeks under conditions prevailing in Tank 48H during the 1995 campaign. 1 Because the accumulating benzene represents a potential safety hazard, the decomposition process is being studied at SRTC. Laboratory studies suggest that catalysis by metals such as copper is responsible for the high rate of decomposition. ${ }^{2} \mathrm{~A}$ wide variety of transition metals are present in the waste sludge, and although they are normally considered insoluble in the caustic solution in which the precipitation is performed; solubilities of a few parts per million for copper and other potentially active elements have been measured. Heterogeneous . reactions involving the solid sludge are also considered possible. The data suggest that the decomposition occurs in a stepwise process, in which the phenyl groups are removed one at a time to form triphenyl, diphenyl, and monophenyl boron compounds. Formation of biphenyl under some conditions suggests that the simultaneous loss of two phenyl groups may also be possible. Observations and laboratory data indicate the decomposition processes have a fairly strong temperature dependence. Additional laboratory studies continue.2,3,4

Oxygen appears to play a significant part in the catalytic decomposition of tetraphenylborate. An induction period has been observed in laboratory tests, ${ }^{2}$ and appears to depend on the oxygen concentration in the solution. Phenol is a significant reaction product, and its formation depends on available oxygen. Early studies by Crawford4 suggest that the rate of phenylboronic acid decomposition in the presence of catalysts also depends on the oxygen concentration.

\section{Responsibilities and Deliverables}

The work described in this plan will be carried out by or under the direction of M. $\dot{L}$. Hyder of the Chemical and Hydrogen Technology Section. 
Deliverables include informal oral or written progress reports, and a final report incorporating all significant findings.

\section{TASK ACTIVTTIES}

\section{Experimental Procedures}

The experimental procedures used in these experiments are based on techniques developed during preliminary scoping studies. Measurements of dissolved oxygen concentration will be performed using a Model 58 YSI oxygen analyzer, in conjunction with its standard \# 5739 probe. This probe contains an electrochemical cell in which dissolved oxygen is reduced in a $\mathrm{KCl}$ solution, and a temperature sensor. The electrochemical cell is separated from its environment by a membrane permeable to oxygen. Oxygen reduction within the cell is rapid and efficient, so the reduction current depends on the rate of diffusion across the membrane. This, in turn, is controlled by the effective partial pressure of oxygen on the outside surface of the membrane. The diffusion rate is the same for gaseous oxygen at a given pressure, and for solutions saturated with oxygen at that pressure. This facilitates frequent calibration of the cell, as it can readily be done in moist air, as recommended by the manufacturer. Calibration of the cell will be made at least daily during these tests.

To prevent oxygen depletion at the surface of the membrane when measuring the oxygen content of the solutions, it is important to stir the solution. The experimental arrangement devised to accomplish this is shown in Figure 1. The solution of interest is introduced through one of the the ball joint connections with the stirrer running. The vessel is filled above the level of the membrane, and the oxygen saturation is recorded as soon as the reading on the meter stabilizes.

The Model 58 analyzer incorporates built-in temperature compensation for temperatures expected in natural waters and the environment. Output is expressed in terms of either mg oxygen per liter or as percentage of saturation; the latter is appropriate for solutions containing enough solutes to affect oxygen solubility. The solutions used in this study are in this category. For this study, the solutions will cool at room temperature for at least one hour, so that the temperature at the time of measurement will be less than $30^{\circ} \mathrm{C}$, within the normal range of temperatures for which the instrument was designed.

The reaction vessel used to contain the solutions during heating is shown in Figure 2. The solution is aerated or deaerated in a separate vessel, and then introduced through the dip leg until the ressel is filled. The filled vessel is then placed in a constant temperature bath with the stopcocks open. Thermal expansion of the solution forces some of it out of the vessel. The stopcocks are then closed and the vessel allowed to remain in the bath for the desired time. At the end of this time the vessel is cooled to ambient temperature and, and a portion of its contents transferred to the oxygen measurement cell by air or nitrogen pressure.

This arrangement has been tested with aerated and deaerated solutions of $1 \mathrm{M}$ $\mathrm{NaOH}$, which is essentially the composition to be used in this study. The probe 
response to solutions purged with nitrogen is less than 1\% of saturation, and solutions purged with air show $100 \%$ saturation. The transfer of solution through plastic lines introduces little oxygen into the cell, particularly if the lines are purged with nitrogen prior to the transfer.

All the heating performed for these experiments is done in a Fisher constant temperature bath set to maintain a nominal temperature of $63^{\circ} \mathrm{C}$. Measurement of the bath temperature under these conditions using a mercury thermometer calibrated against NIST standards by the SRS Standards Lab showed that this maintains an actual bath temperature of $59^{\circ} \mathrm{C}$. This bath has a capacity of seven of the reaction vessels described above.

Composition analyses of reacted solutions will be performed by the Analytical Services Division using established techniques. High pressure liquid chromatography (FPLC) will be used to measure tetraphenylborate ion and its decomposition products, including phenol.

The preparation of solutions will use standard gravimetric and volumetric methods. Laboratory grade sodium tetraphenylborate and phenylboronic acid from Aldrich Chemical will be measured gravimetrically to make up stock solution. Other chemicals will be reagent grade. Standard laboratory glassware (graduated cylinders) will be used to make up volumes.

Aeration of solutions will be done by sparging them through a fritted glass bubbler with compressed air for at least five minutes. Preliminary measurements using the oxygen probe have shown this method essentially saturates the solution with oxygen. Removal of oxygen for solutions that are used in oxygen-free tests is done by purging the solutions with nitrogen by five to ten minutes.

\section{Scoping Experiments}

Scoping experiments were conducted to elucidate the behavior of oxygen in solutions of interest and to plan more detailed studies. Significant findings include the following.

- Solutions of $\mathrm{NaTPB}$ in $1 \mathrm{M} \mathrm{NaOH}$, saturated with $\mathrm{Cu}$, reacted only slowly at $60^{\circ} \mathrm{C}$ when the $\mathrm{NaTPB}$ concentration was 2 or $10 \mathrm{~g} / \mathrm{L}(0.006$ or $0.03 \mathrm{M})$. At the $0.006 \mathrm{M}$ concentration no discernable reaction (as measured by decrease in TPBconcentration) was observed in aerated solutions over periods of about 150 hours. In deaerated solutions at this initial concentration, the TPB- concentration decreased by about 3.5\% over about 200 hours of heating, and triphenylboron and phenol production were observed. (Diphenyl and monophenylboronic acids were not detected.) In aerated $0.03 \mathrm{M}$ solutions some decrease of oxygen concentration was observed over about 160 hours at $60^{\circ} \mathrm{C}$, although the measurements were erratic. These results are conisistent with the results of Barnes. ${ }^{2}$

- One scoping experiment using $0.03 \mathrm{M}$ NaTPB showed significant decomposition of the TPB-ion in the presence of simulated sludge solids, under conditions that produced little or no reaction in the absence of such solids. 
- Dissolved copper at concentrations ranging from 5 to $30 \mathrm{mg} / \mathrm{L}$ was observed in aerated $1 \mathrm{M} \mathrm{NaOH}$ solutions contacted with copper metal, cuprous oxide, or cupric oxide. The copper measurements scattered considerably, and no systematic trend of copper solubility was established. The analytical methods used did not permit determining the oxidation state of dissolved copper.

- Cuprous oxide reacts readily with dissolved oxygen in $1 \mathrm{M} \mathrm{NaOH}$, effectively deoxygenating the solution and forming a layer of dark cupric oxide. Deoxygenation of TPB- solutions by cuprous oxide made possible the measurements of deaerated TPB- solutions as described above.

- Phenylboronic acid at $2 \mathrm{~g} / \mathrm{L}(0.016 \mathrm{M})$ in $1 \mathrm{M} \mathrm{NaOH}$ at $60^{\circ} \mathrm{C}$, in the presence of about $10 \mathrm{ppm} \mathrm{Cu}$, decomposes, reacting with all available dissolved oxygen in the process. The copper present is apparently converted to $\mathrm{Cu}(\mathrm{I})$, as indicated by the absence of any black CuO and the presence of a small amount of off-white to light tan precipitate. The observed decomposition is consistent with undocumented results of C. L.: Crawford (personal communication). The reaction apparently stops when the oxygen is exhausted. In scouting tests, phenylboronic acid did not decompose significantly in the absence of oxygen, even though copper was present.

\section{Experimental Program}

Five series of experiments are planned. For the first four series the starting composition of all solutions will be identical; only the time at temperature $\left(60^{\circ} \mathrm{C}\right)$ will vary. Individual containers will be withdrawn from the constant temperature bath according to a predetermined schedule, as shown below, and analyzed for dissolved oxygen, organic boron compounds, and phenol. All samples will be air saturated by sparging before they are placed in the glass vessels for heating. Each sample will be equilibrated with the bath for approximately 30 minutes before the stopcocks are closed. This effects the removal of air bubbles, and prevents the breakage of the vessels by thermal expansion during heating.

The fifth series will be a set of scoping studies to determine the behavior of triphenylboron and diphenylboric acid with regard to oxygen, at the temperature of $60^{\circ} \mathrm{C}$.

Series One: Phenylboronic Acid. This series of experiments is intended to elucidate the rate of reaction of phenylboronic acid before and after the dissolved oxygen is consumed. The results from this study will be combined with those from scoping studies to derive the desired rates. The composition will be identical to that of the scoping studies, $\mathrm{i}$. e., air saturated, $2 \mathrm{~g}$ phenylboronic acid per liter in $1 \mathrm{M}$ $\mathrm{NaOH}$, and approximately $10 \mathrm{mg} / \mathrm{L} \mathrm{Cu}$. Samples will be withdrawn from the bath for analysis of oxygen, PBA, and phenol after approximately 16 hours, 24 hours, 40 hours, 64 hours and 4 days. (Corresponding times for the first scoping study were 2, $.5,7$, and 12 days.) In addition, as a control, two deaerated samples of similar composition will be heated for two and four days and analyzed. 
Approximately four samples will also be studied to determine the behavior of PBA at lower concentrations of PBA and of Cu. Two of these samples will be prepared at approximately $0.5 \mathrm{~g} / \mathrm{L} \mathrm{PBA}$ and $10 \mathrm{mg} / \mathrm{L} \mathrm{Cu}$; the other two will be $2 \mathrm{~g} / \mathrm{L} \mathrm{PBA}$ and 2.5 mg/L Cu.

Series Two: Tetraphenylborate. This series of experiments will determine the effect of oxygen on the rate of tetraphenylborate decomposition. As suggested by prior experiments, in which the most rapid decomposition was observed at the highest TPB- concentrations, the concentration of tetraphenylborate will be increased from that previously used. Samples will be initially air saturated. Approximately $25 \mathrm{~g}$ NaTPB per liter in $1 \mathrm{M} \mathrm{NaOH}$ will be used, along with $10 \mathrm{mg} / \mathrm{L}$ $\mathrm{Cu}$. This experiment is expected to require up to two weeks, and the exact times will be determined after analysis of the initial samples in order to get a sufficient number of samples before and after oxygen depletion. A series of five samples is planned with the first sampling being made at about 5 days. This work has already been initiated, as an extension of the scoping work previously conducted.

Series Three: Tetraphenzlborate and Simulated Sludge. This is a follow-on to the scoping experiment in which simulated sludge solids were found to catalyze decomposition of TPB- in alkaline solution. Air-saturated samples of $10 \mathrm{~g} / \mathrm{L} \mathrm{NaTPB}$ in $1 \mathrm{M} \mathrm{NaOH}$ will be heated in the presence of approximately $2 \mathrm{~g} / \mathrm{L}$ sludge solids for periods of approximately 2,4 , and 6 days. The solutions will then be analyzed for oxygen content, TPB-, and its decomposition products.

Series Four: Phenylboronic.Acid and Tetraphenylborate. In this experiment the decomposition of phenylboronic acid will remove the dissolved oxygen and presumably convert $\mathrm{Cu}^{++}$to $\mathrm{Cu}^{+}$. The decomposition of tetraphenylborate will then be followed over time. Initial concentrations will be $2 \mathrm{~g} / \mathrm{L} \mathrm{PBA}, 10 \mathrm{~g} / \mathrm{L} \mathrm{NaTPB}$, and $10 \mathrm{mg} / \mathrm{Cu}$. Samples will be recovered at 1, 2, 3, 6, 9, and 14 days, and analyzed for oxygen, TPB-, PBA, phenol, triphenylboron, and diphenylboric acid.

In the latter two studies, additional samples may be added to provide additional detail near inflection points, if the data suggest the need. In the studies using phenylboronic acid, sampling for copper concentration will be made to attempt to determine copper solubility in $1 \mathrm{M} \mathrm{NaOH}$ under reducing conditions. The solution will be mixed with a known excess of nitric acid at the time of sampling, to ensure stability, and submitted to ASD for analysis.

Series Five: Scoping Studies of Triphenylboron and Diphenvlboric Acid. Scoping studies will be conducted to determine whether oxygen participates in the coppercatalyzed decomposition of these degradation products of tetraphenylborate. Solutions of each of these compounds will be heated in the presence of oxygen and copper, and the amount of degradation and oxygen consumption measured. Heating times will be selected based on analysis of past experiments involving copper-catalyzed hydrolysis of tetraphenylborate ion. 


\section{Quality Controls}

The oxygen probe shall be calibrated daily in conformance with the manufacturer's instructions. The water bath temperature will be checked weekly with a thermometer calibrated by site standards, and therefore traceable to NIST. Compositional analyses made by ADS will be performed according to the procedures of that organization. These analyses and their quality control procedures have been developed for work related to this study, and are believed adequate for this study. Samples of each unreacted stock solution shall be analyzed as a cross-check on solution preparation.

Programmatic Risks and Mitigations

Programmatic risks and mitigations are shown in Table I.

\section{Reports}

A final report shall be written summarizing and interpreting these studies. Informal interim reports shall be made as requested by WPS management.

\section{Safety}

No new safety hazards or new hazardous chemicals will be introduced into the laboratory in the course of this work. Established laboratory procedures will be followed, including those for use of electrical equipment, handling corrosive chemicals (sodium hydroxide), and handling and manipulating laboratory glassware.

\section{SCHEDULE}

December 13, 1996

December 31, 1996

January 2, 1997

January 24, 1997

January 31, 1997

February 14, 1997
Issue Task Plan, intiate series 1 and 3

Complete Test Series 1,2 , and 3

Begin Test Series 4 and 5

Complete Test Series 4

Complete Test Series 5

Issue Final Report

\section{REFERENCES}

1. D. D. Walker, M. J. Barnes, C. L. Crawford, R. F. Swingle, R. A. Peterson, M. S. Hay, and S. D. Fink, Decomposition of Tetraphenylborate in Tank 48H (U), WSRCTR-96-0113, Rev. 0, May 10, 1996.

2. M. J. Barnes and T. B. Edwards, Copper Catalyzed Sodium Tetraphenylborate Decomposition Kinetic Studies (U), WSRC-TR-96-0351, Rev. 0, November 7, 1996.

3. D. D. Walker and C. A. Nash, Results from Tank $48 H$ Slurry Decontamination and Decomposition Experiments in Support of ITP Process Verification Testing (U), WSRC-TR-96-0190, September 6, 1996. 
4. C. L. Crawford, Task Technical Plan for Decomposition Studies of Tetraphenylborate Slurries (U), WSRC-RP-96-549, Rev. 0, October 23, 1996. 
M. L. Hyder

WSRC-RP-96-0612, Rev. 0

Page 9 of 10

TABLE I

PROGRAMMATIC RISKS AND MITIGATIONS

Risk Factor

Event

Mitigation

Equipment:

Oxygen probe

Failure

Failure

Failure

Water bath

Glassware

Breakage

Install new membrane (on hand) Repair or replace

Repair or replace

Replace

Note: The oxygen probe, its electronics, and the water bath are commercial items, and readily replaceable from the commercial sources. The glassware was made in the SRTC shop, and can be replaced within a day if necessary.

Analytical support:

HIPLC

Copper

Personnel

M. L. Hyder

Facility:
Failure of equipt. or loss of personnel

Unavailability due to illness, etc.

Facility outage
ADS is installing backup equipment and training additional staff for HPLC analyses.

Other personnel can assume work, but with some loss of time.

Short outages of electricity or ventilation will not have a major effect. A sustained outage could lengthen the schedule. 
WSRC-RP-96-0612, Rev. 0

Page 10 of 10
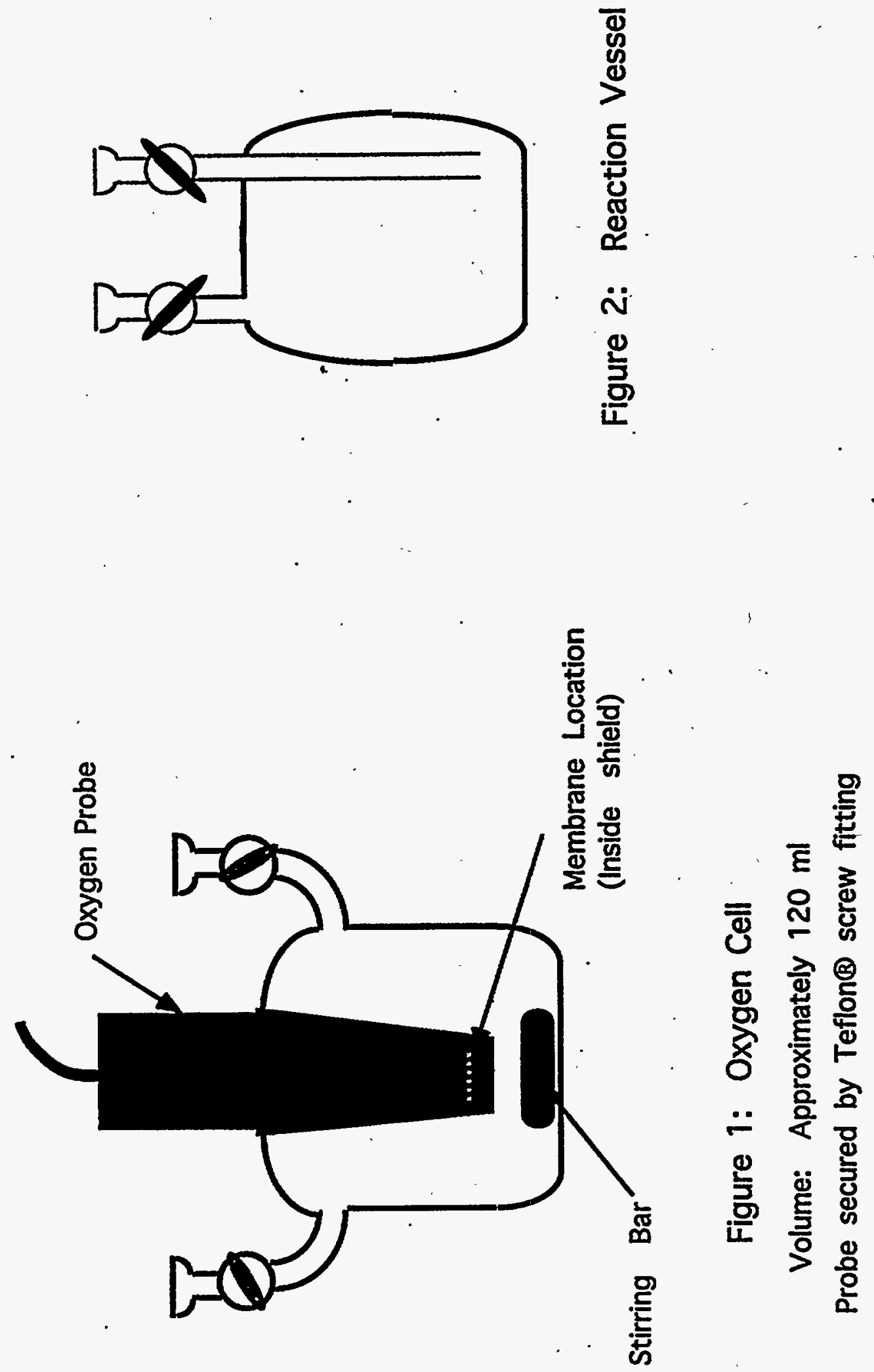


\section{DISTRIBUTION}

Amerine, D. B., 241-121H

Barnes, J. L., 241-121H

Barnes, M. J., 773-A

Britt, T. E., 730-2B

Carter, J. T., 704-25S

Cauthen, G. L., 241-119H

Clark, W. C., 241-119H

Cloessner, P., 773-A

Crawford, C. L., 773-43A

Doughty, D. E., 704-56H

Eberlein, S. J., 241-121H

Elder, H. H., 704-S

Fink, S. D., 773-A

Fowler, J. R., 241-121H

Griffin, J. C., 773-A

Hitchler,'M. J., 730-2B

Holtzscheiter, E. W., 773-A

Hyder, M. L, 773-A

Jacobs, R. A., 704-T

Johnson, M. D., 704-56H

Keefer, M. T., 704-56H

Landon, L. F., 704-T

Lewis, R. L., 704-H

Lex, T. J., 719-4A

Lowe, P. E., 773-41A

Marek, J. C., 704-T
Marra, J. E., 704-56H

McCabe, D. J., 773-43A

Menna, J. D., 241-119H

Miller, M. S., 704-72S

Montini, M. J., 704-S

Morin, J. P., 719-4A

Nash, C. A., 773-A

Nelson, L. M., 773-43A

Papouchado, L. M., 773-A

Peterson, R. A., 773-A

Randall, C. T., 704-T

Rutland, P. L., 241-152H

Satterfield, R. M., 719-4A

Swingle, R. F., 773-A

Tamosaitis, W. L., 773-A

Taylor, G. A., 703-H

Tovo, L., 773-A

Van Pelt, W. B., 676-1T

Walker, D. D. 773-A

Wiggins, A. W., 241-152

Wooten, A. L., 732-B

Wright, G. T., 773-A

TIM, 703-43A

LWP Files, c/o A. Patterson, 773-A

ITP Files, c/o A. Lemay, 241-121H 